\title{
Effects of three different biochars on aggregate stability, organic carbon mobility and micronutrient bioavailability
}

by Hartley, W., Riby, P. and Waterson, J.

Copyright, Publisher and Additional Information: This is the author accepted manuscript. The final published version (version of record) is available online via Elsevier Please refer to any applicable terms of use of the publisher.

DOI: http://dx.doi.org/10.1016/j.jenvman.2016.07.023

Harper Adams

University

Hartley, W., Riby,P. and Waterson, J. 2016. Effects of three different biochars on aggregate stability, organic carbon mobility and micronutrient bioavailability. Journal of Environmental Management, 181, pp.770-778. 


\section{Effects of three different biochars on aggregate stability, organic carbon mobility and micronutrient bioavailability.}

William Hartley $^{1 *}$, Philip Riby ${ }^{2}$, James Waterson ${ }^{1}$

${ }^{1}$ Department of Crop and Environment Sciences, Harper Adams University, Newport, Shropshire, TF10 8NB

${ }^{2}$ School of Biomolecular Sciences, Liverpool John Moores University, Byrom Street, L3 3AF

E-mail address: whartley@ harper-adams.ac.uk

Abstract. Previous studies have demonstrated both beneficial and detrimental effects on soil properties from biochar incorporation. Several biochars, with different feedstock origins, were evaluated for their effectiveness at improving soil quality of a sandy agricultural soil. A pot trial was used to investigate aggregate stability and microbial activity, pore water trace element mobility and micronutrient concentrations in grain of spring wheat after incorporation of three biochars. The feedstocks for biochar production were selected because they were established UK waste products, namely oversize woody material from green waste composting facilities, and rhododendron and soft wood material from forest clearance operations. Biochars were incorporated into the soil at a rate of $5 \% \mathrm{v} / \mathrm{v}$. Aggregate stability was improved following addition of oversize biochar whilst microbial activity increased in all treatments. Dissolved organic carbon (DOC) concentrations in soil pore water from biochartreated soils were raised, whilst micronutrient concentrations in wheat grain grown in the treated soils were significantly reduced. It was concluded that incorporation of biochar to temperate agricultural soils requires caution as it may result in reductions of essential grain micronutrients required for human health, whilst the effect on aggregate stability may be linked to organic carbon functional groups on biochar surfaces and labile carbon released from the char into the soil system.

Keywords: biochar; organic carbon; aggregate stability; microbial activity; micronutrients 


\section{Introduction}

The incorporation of biochar to improve impoverished agricultural soils is not a new phenomenon, indeed its historical use dates back at least 2000 years (O’Neill et al., 2009). Biochars' potential to sequester carbon in the soil, and prevent it from being released to the atmosphere, has attracted the greatest attention (Liang et al., 2008; Woolf et al., 2010). Still, incorporation of biochar to improve soil quality and plant growth are also of importance, as biochar has been shown to have a significant influence on soil properties such as microbial activity and soil structural stability (Lehmann and Joseph, 2009).

Aggregate stability and associated microbial activity are important factors in assessing soil sustainability. Aggregate stability is a measure of a soils structural resilience and its potential to maintain long-term crop productivity by encouraging root penetration, maintaining soil temperature and gas diffusion, improving water transport and enhancing seedling emergence. Ouyang et al., (2013) observed enhanced macroaggregate formation in a sandy loam soil amended with biochar produced from dairy manure. It was suggested that the relatively higher $\mathrm{C} / \mathrm{N}$ ratio of the biochar favoured fungal growth, enhancing aggregate stability (Bossuyt et al., 2001). Nevertheless, data are scarce on the development of aggregate stability in biochar-amended soils (Mukherjee \& Lal, 2013) and as a relatively new soil amendment, its effect on soil physical properties still requires further research (Atkinson et al., 2010).

Clearly, the physicochemical nature of biochar will depend upon the type of organic feedstock and the process by which it is produced. There are many possible combinations of feedstocks, conversion technologies, and application systems, yet much of what has been reported in the literature is theoretical (Brick, 2010). Production temperature will have an effect on the surface area and pore volume of the biochar. The porous nature and surface chemical properties are important factors that will govern the adsorptive capabilities of 
biochar once it is applied to soil (Mukherjee \& Lal, 2013). This is a significant feature that will ultimately dictate its quality and ability to improve temperate agricultural soils. There are also many potential feedstocks ranging from straw, sludge and woodchip (Sun and Lu, 2014) to those derived from waste products such as sawdust (Liu et al., 2012).

Waste products are an attractive option for biochar feedstocks. In this respect, an important consideration is the current European Union requirement to divert biodegradable wastes from landfill, limiting decomposition and reducing methane production. In the UK, legislation has given considerable impetus to the production of soil-improvement composts derived from domestic green waste. Nevertheless, as a result of the garden waste composting process, a woody 'oversize' fraction is generated which causes problems for site operators due to space constraints and odour problems; this material is either chipped or in most cases sent to landfill. Other surplus woody materials that may also have the potential to become important feedstocks are those generated from Rhododendron (Rhododendron ponticum), Larch (Larix kaempferi) and Sitka Spruce (Picea sitchensis) clearance. For example Rhododendron ponticum is a widely-established invasive species, and is a nuisance particularly in north and west UK, and therefore is frequently targeted for control or removal on environmentally significant sites. In all cases the resulting woody material is typically disposed of by mechanical mulching or by controlled burning on site.

Considerable work is necessary to evaluate soil-quality indicators following biochar application, but more importantly, different feedstocks must be sufficiently investigated as they may respond differently in temperate soils (Novak and Busscher, 2012; Sun and Lu, 2014). Furthermore, there are conflicting results in the literature regarding the effect of biochar on sandy soils and there is a need to understand the effects of this product on different soil types on a char by char basis (Molnár et al., 2016). Molnár et al., (2016) also noted that investigations focusing on the complex effects of different biochars on sandy soils 
are scarce. Biochars are inherently variable due to differences in production technologies and feedstock and caution must be used when applying them to agricultural soils. Not all biochars have been shown to enhance agricultural productivity (Van Zwieten et al., 2010), with limited information existing about soil-biochar interactions. Thus far, this product has little use in commercial agriculture (Liang et al., 2015). Due to the irreversibility of biochar application to soil, comprehensive studies must be performed to achieve confidence that its incorporation does not negatively affect soil health and productivity (De la Rosa et al., 2014). As a consequence of this uncertainty, pot investigations are required as proof-of-principle studies, prior to field application.

Therefore the objectives of the present work were to evaluate the effects of three biochars (pyrolysed 'oversize' woody material, rhododendron and softwood) incorporated into a sandy soil on (i) aggregate stability and microbial activity (ii) mobilisation of carbon and trace elements in pore waters and (iii) micronutrient $(\mathrm{Zn}, \mathrm{Cu}, \mathrm{Mn}$ and $\mathrm{Fe}$ ) bioavailability to wheat.

\section{Materials and methods}

\subsection{Feedstocks and biochar production}

All feedstocks were identified and characterised as widely available at the UK level and as being co-products or residues, rather than mainstream wood supply chain materials. The three feedstocks used were as follows:

1) The 'oversize' woody biomass (cited as 'OS' from here on) screened-out during the composting of municipal and domestic green waste. This material causes many operational issues for compost site operators taking up valuable storage space and creating odours if not removed regularly from the site. 
2) Rhododendron (Rhododendron poniticum) is an invasive shrub of woodlands and commercially managed forests (cited as 'RD' from here on). The biomass generated from clearing operations results in the production of excess carbon to the atmosphere as a result of burning the waste material.

3) Soft wood biomass (cited as ' $\mathrm{SW}$ ' from here on) mainly consisting of Japanese Larch (Larix kaempferi) and Sitka Spruce (Picea sitchensis) wood residues from large-scale commercial forestry harvesting operations, present in approximately equal proportions.

Conversion of the three feedstocks into biochar was carried out in an Exeter Biochar Retort. The retort chamber was $1.7 \mathrm{~m}^{3}$ and fully insulated with a ceramic blanket. Steam production decreased at $375^{\circ} \mathrm{C}$ and the gases which subsequently formed were diverted into the firebox and ignited. This is referred to as the exothermic or retorting stage (which is kept below $500^{\circ} \mathrm{C}$ ) and completes the pyrolysis process. For additional operational details of the retort device see: http://biocharretort.com/index.html. Each feedstock was converted into biochar separately in individual batches, with a retort temperature of $430-440^{\circ} \mathrm{C}$ which was maintained throughout the conversion process ( $\sim 4$ hours). Biochar was subsequently milled in separate batches using a proprietary feed mill (Novital Nuovo Ercolino 1500 watt electric mill) to provide a consistent size fraction $(4.0 \mathrm{~mm})$.

\subsection{Soil collection and preparation}

The soil used in this investigation was a Typic Arenic Endoleptic Regosol, Bridgnorth series. Bulk surface soil samples $(0-10 \mathrm{~cm})$ where obtained from Harper Adams University, Shropshire, $\left(52^{\circ} 46^{\prime} 19.9^{\prime \prime} \mathrm{N} 2^{\circ} 25^{\prime} 31.1^{\prime \prime} \mathrm{W}\right)$, using an excavator. The soil was subsequently air-dried and then sieved $(<4 \mathrm{~mm})$. Table 1 provides the main characteristics of the untreated soil. A sub-sample was taken from the homogenised soil and further crushed and 
sieved to a particle size of $<2 \mathrm{~mm}$ diameter, then $\mathrm{pH}$, organic matter content, total organic carbon (TOC), and total elemental concentrations were determined prior to experimental use (Section 2.8, Analytical Methods). Biochar amendments were applied to the homogenised soil at a rate of $5 \% \mathrm{v} / \mathrm{v}$. Amended soils were homogenised thoroughly using a cement mixer, then moistened to $70 \%$ of the soil water holding capacity (WHC) with tap water and allowed to equilibrate for 14 days prior to being transferred to plastic pots.

\subsection{Plant growth study}

Plastic pots (15 kg capacity; $32 \mathrm{~cm}$ diameter) were filled with the amended soils prepared as described above and 10 spring wheat seeds (Triticum aestivum L. Belvoir) were sown at approximately $1 \mathrm{~cm}$ deep to each pot/treatment. Each treatment was evaluated in triplicate. Treatments were also investigated but without the addition of wheat (unplanted) and were also carried out in triplicate. The investigation was maintained in a controlled glasshouse environment $\left(21 \pm 2^{\circ} \mathrm{C} ; 60 \%\right.$ R.H.; $12 \mathrm{~h}$ light $)$ with regular daily watering (tap water). Plants were grown until grain maturity.

\subsection{Harvesting of wheat grain}

Grain was harvested and separated into husk and seeds. Grains were washed with deionised water to remove soil residues, blotted with tissue paper until dry, weighed fresh then oven dried at $35^{\circ} \mathrm{C}$ for five days. Dried biomass was re-weighed then ground in a stainless steel mill (Pulverisette 15). Ground samples were stored in polyethylene containers prior to microwave digestion and analysis by ICP-MS (Section 2.8, Analytical Methods). 


\subsection{Soil pore water sampling and collection}

Once filled with soil, a hole was drilled in the side of each pot $10 \mathrm{~cm}$ below the lip and a 'Rhizon' soil pore water sampler (Eijkelkamp Agrisearch Equipment, Giesbeek, The Netherlands) inserted at a $45^{\circ}$ angle. These consist of a porous polymer tube $(10 \mathrm{~cm})$ at one end that is inserted into the soil. This is connected to a PVC tube $(10 \mathrm{~cm})$ and a Luer-Lock connector, from which pore water is obtained using a syringe and vacuum tube (Clemente et al., 2008). Pore water samples were analysed for $\mathrm{pH}$, dissolved organic carbon (DOC), and the micronutrients iron $(\mathrm{Fe})$, manganese $(\mathrm{Mn})$, zinc $(\mathrm{Zn})$ and copper $(\mathrm{Cu})$ for all treatments and controls.

\subsection{Aggregate size distribution and determination of aggregate stability}

Aggregate size distribution was firstly determined by dry sieving. In the dry sieving method, $100 \mathrm{~g}$ of $<4 \mathrm{~mm}$ air-dried aggregates were gently sieved for 5 minutes using a column of five sieves $(4,2,1,0.25$ and $0.063 \mathrm{~mm})$. Stability of aggregates was defined as $M W D_{D}$. The mean weight diameter $\left(M D_{D}\right)$ of each sieve sample was calculated using the following equation (1):

$$
\mathrm{MWD}_{\mathrm{D}}=\sum_{\mathrm{i}=1}^{\mathrm{n}} \overline{\mathrm{X}_{\mathrm{i}}} \times \mathrm{W}_{\mathrm{i}}
$$

Where $\bar{X}_{\mathrm{i}}$ is the mean diameter over each portion $(\mathrm{mm}), \mathrm{W}_{\mathrm{i}}$ is the percentage of aggregates in that size range and $\mathrm{n}$ is the number of sieves (Le Bissonnais, 1996).

For the wet sieving method, using one single sieve, (Kemper and Rosenau, 1986), $2.0 \mathrm{~g}\left(\mathrm{~W}_{\mathrm{t}}\right)$ of air-dried aggregates with a MWD equal to $1.5 \mathrm{~mm}$ (a mean of the selected soil aggregates between 2 and $1 \mathrm{~mm}$ sieve openings) were placed on a sieve (mesh size $0.250 \mathrm{~mm}$ ) (d) and sieved in a stainless steel can containing deionised water for 3 min using a commercial wet sieving apparatus (Eijkelkamp Agrisearch Equipment, Giebeek, the Netherlands). Stable 
aggregates $\left(\mathrm{W}_{\mathrm{s}}\right)$ that remained above the sieve were subsequently oven-dried and weighed and $\mathrm{MWD}_{\mathrm{W}}$ was calculated using equation (2):

$$
\mathrm{MWDW}_{\mathrm{W}}=\frac{\mathrm{W}_{s} \times \mathrm{d}}{\mathrm{W}_{t}}
$$

Where $s$ is the weight of soil aggregates in the sieve, $d$ is the mesh size and $t$ is the weight of air-dried soil aggregates prior to sieving (Saygin et al., 2012).

\subsection{Soil respiration}

Soil respiration ( $\mathrm{CO}_{2}$ evolution) was determined using an ADC Bioscientific Ltd LCpro soil respirometer. Stainless steel collars were inserted into the test soils at the start of the investigation and left in situ to stabilise for 2 weeks (Hartley et al., 2008). For measurement of $\mathrm{CO}_{2}$ evolution, the soil hood of the respirometer was attached to the stainless steel collar and respiration rate recorded after the reading had stabilised (usually after 20 minutes). Measurements were determined in triplicate.

\subsection{Analytical methods}

Total carbon (TC), organic carbon (TOC) and inorganic carbon (IC) were determined using a Shimadzu TOC-Vcsn solid and liquid sample module (TOC-VE/SSM-5000A) (Shimadzu, Tokyo, Japan). For TC, soil samples $\left(30 \mathrm{mg}\right.$ ) were placed in a furnace at $900^{\circ} \mathrm{C}$, for IC soil samples $(30 \mathrm{mg})$ were treated with phosphoric acid $\left(\mathrm{H}_{3} \mathrm{PO}_{4}, 5 \mathrm{ml}\right)$ and then placed in a furnace at $200^{\circ} \mathrm{C}$. Particle size analysis of the air-dried soil was determined using a laser diffraction particle size analyser (Beckman Coulter LS 13320) according to the following classification: $2 \mathrm{~mm}-63 \mu \mathrm{m}$ (sand), $62.9-2 \mu \mathrm{m}$ (silt) and $<2 \mu \mathrm{m}$ (clay). ICP-MS (XSERIES 2, ICP-MS; Thermo Scientific, MA, USA) was used for metals analysis of soils 
and pore waters. Gallium (Ga) was added as an internal standard to all samples $\left(10 \mu \mathrm{g}^{-1}\right)$ and used to calculate concentrations and correct for a decrease in signal during analysis. Accuracy was checked by reference to international certified standard water (NWRI-TMDA-62). Potassium, $\mathrm{Ca}$ and $\mathrm{Mg}$ were extracted from air-dried soil $(<2 \mathrm{~mm})$ using ammonium acetate $\left(\mathrm{C}_{2} \mathrm{H}_{3} \mathrm{O}_{2} \mathrm{NH}_{4}\right)(1 \mathrm{M})$, and shaken for 1 hour. The solution was then filtered and analysed using a Perkin Elmer Atomic Absorption Spectrometer (AAS). X-ray fluorescence (XRF) (Shimadzu, EDX720 energy dispersive X-ray spectrometer) was used to determine total element concentrations in soil. Air-dried soil $(<2 \mathrm{~mm})$ was gently pressed into $25 \mathrm{~mm}$ diameter sample cells having an Ultralene $\mathrm{x}$-ray film (4 $\mu \mathrm{m}$ thick) (Spex Certiprep, Middlesex, UK), measurement duration was 100 seconds, $40 \%$ dead time under vacuum. Soil $\mathrm{pH}$ was determined using a $20 \mathrm{~g}$ dry sample mixed to a slurry with deionised water (50 $\mathrm{ml}$ ), and the supernatant tested using a digital Jenway $\mathrm{pH}$ meter and probe. Electrical conductivity (EC) was tested on the same sample using a Cyberscan Con 11 conductivity meter and probe. Organic matter content was determined by loss-on-ignition (LOI) $\left(450^{\circ} \mathrm{C}\right)$. All analyses were carried out in triplicate.

Wheat grain and soil samples were digested using a CEM Mars Xpress microwave digestion instrument (programme; 1600w $100 \%$ power $10 \mathrm{~min}$; hold $160^{\circ} \mathrm{C} 20 \mathrm{~min}$ ). Dry, finely ground material was weighed $(0.2 \mathrm{~g})$ into dry acid-washed digestion vessels $(120 \mathrm{ml})$ to which Analar grade $14 \mathrm{M} \mathrm{HNO}_{3}(10 \mathrm{ml})$ was added. Digests were carried out in triplicate and analysed via ICP-MS (XSERIES 2 ICP-MS; Thermo Scientific, MA, USA); Gallium (Ga) was used as an internal standard and added to all samples $\left(10 \mu \mathrm{g}^{-1}\right)$. Bowens Kale powder (Bowen, 1974; Katz, 2002) was used as a standard reference plant material for QA purposes. SEM images of the biochar samples were taken using a Cambridge Instruments Stereoscan S200. Spectrographs for biochar carbon functional groups were taken using Fourier transform infrared spectroscopy (FT-IR) (Bruker Alpha-P FTIR spectrometer) using a 
germanium (Ge) ATR (attenuated total reflection) crystal unit. Each biochar was scanned 1000 times to reduce signal to noise.

\subsection{Statistical analysis}

Statistical analyses were performed using SPSS Ver. 23 for windows. Data were checked for normality and one-way ANOVA and LSD (least significant difference) were used to test for differences between biochar-treated and untreated soils. Where data were not normally distributed, Kruskal-Wallis followed by Mann-Whitney U was used to test for differences between pairs.

\section{Results and discussion}

\subsection{Soil and amendments}

The soil had a high sand content, typical of the Bridgnorth series; soil carbon was mainly present in organic form, with a low organic matter content and a circumneutral $\mathrm{pH}$ (Table 1). Metal concentrations were in the normal range for mineral (but not organic) soils in the UK. Biochar is well known to vary according to feedstock and production process: in this case the biochars had total carbon (TC) concentrations ranging from $53-89 \%$ and were alkaline in nature (Table 2). Surface structures of the biochars, as revealed by SEM images, displayed similar pore structures, probably as a result of the pyrolysis temperature (Fig. S1). All biochars showed rectangular structures and thin cell walls indicating loss of organic matter due to the pyrolysis temperature (Iqbal et al., 2015). Oversize biochar typically had higher EC and total S concentration, but lower TC than the other chars (Table 2). Compared to untreated soils, incorporation of the biochars increased $\mathrm{pH}$, organic matter and TC (Table 3). 
After 12 months, unplanted biochar-treated soils (UP) revealed a decrease in $\mathrm{pH}$ but organic matter remained constant whilst TC increased (Table 3).

The C:N ratio increased in soils that had biochar additions, most likely as a result of the chars recalcitrance to microbial breakdown, but also plant uptake and leaching of $\mathrm{N}$ from the pots. Untreated soil planted with wheat also showed a large increase in $\mathrm{C}: \mathrm{N}$ ratio probably due to $\mathrm{N}$ depletion by the plants during the course of the investigation. Differences in biochar surface organic functional groups were identified using FT-IR (Fig. 1). Band assignments are presented in Table 4. FT-IR spectrographs displayed the presence of olefin and aromatic alcohol $\mathrm{CH}$ functional groups and carboxyl $(\mathrm{C}=\mathrm{O})$ groups which are in agreement with other studies (Wiedner et al., 2013, Zhang et al., 2015); the presence of these negatively charged carboxyl groups are mainly responsible for the high cation exchange capacity (CEC) of biochars (Chan and $\mathrm{Xu}, 2009)$. However, OS biochar also revealed ester functional groups possibly resulting from the heterogeneous provenance of this material in comparison to the other chars, which originated from single species or less diverse source materials (Fig. 1, Table 4).

\subsection{Micronutrient mobility and dissolved organic carbon}

There is still widespread debate about the use of biochar and its benefits to agricultural soil (Abujabhah et al., 2016) and there is some evidence to suggest neutral to detrimental effects of biochar on crops (Jay et al., 2015). Although strongly adsorbing phosphate (Lehmann, 2007), biochar has been previously shown to result in high concentrations of bioavailable nutrients (Lehmann et al., 2003). In this study none of the biochar amendments had any significant effect on wheat grain yield compared to control soils (Fig. 2) (p = 0.970), but a clear effect of amendment addition on plant micronutrient uptake was evident; iron (Fe) and 
copper $(\mathrm{Cu})$ concentrations in wheat grain were reduced in all biochar treated soils, whilst zinc (Zn) was significantly reduced in RD treatments $(\mathrm{p}=<0.05)$ (Fig. 3).

Micronutrient deficiencies in humans exist in both developing and developed countries (Genc et al. 2005; Thompson 2011) and can be considered as hidden hunger. Cakmak et al., (1999) noted that domestication and modern cultivation of wheat has resulted in reduced $\mathrm{Zn}$ concentrations in the seed; one third of civilisation is deficient in $\mathrm{Zn}$, with deficiency rates in several countries ranging from 4 to $73 \%$ (Hotz and Brown, 2004). As a consequence, addition of RD biochar to agricultural soils may exacerbate this problem. In a study by Moreno-Jiménez et al., (2016), they discovered that addition of oak-derived biochar had minimal effect on $\mathrm{Zn}$ and $\mathrm{Cu}$ fortification of barley grain, which they suggested may have been due to high cation exchange capacity (CEC), high biochar application rate and $\mathrm{pH}$ buffering. However, it is also understood that genetic variation between cultivars can affect Zn uptake (McLaughlin et al., 1994). An investigation into the effect of biochar amendments on Zn uptake in vegetables by Gartler et al., (2013), only studied one specific cultivar of each vegetable variety; they stated that their results were not applicable to all cultivars of the same crop species used within the study. Correspondingly in this study, only one wheat cultivar was investigated, and differences between cultivars may affect micronutrient uptake. Therefore further investigations are necessary in order to ascertain this.

Iron is more problematic due to its already lower bioavailability in soil (Ortiz-Monasterio et al., 2007) and it was significantly reduced in grain from all biochar treatments compared to controls (Fig. 3). Limited Fe availability negatively affects leaf chlorophyll concentrations (Abadía and Abadía, 1993) and may reduce yield (Álvarez-Fernández et al., 2006). In a pot experiment, Sorrenti et al., (2016) discovered that kiwifruit showed Fe chlorosis symptoms in biochar-treated soils. With the exception of planted OS-treated soil, Fe concentrations were also significantly reduced in pore waters $(\mathrm{p}<0.05)$ indicating a reduction in Fe mobility and 
hence availability for plant uptake (Fig S2). Kappler et al., (2014) suggested that biochar acted as an electron shuttle by mediating electron transfer processes which may have resulted in Fe becoming oxidised on its surfaces. Any ferrous iron in solution may have been electrostatically attracted to the surface of the char by reactive carboxylic and phenolic functional groups (Lin et al., 2012).

Pore water DOC concentrations are presented in Fig 4. We found that with the exception of SW-planted soils, DOC increased significantly in soil pore waters (Fig 4; Table S1) which may offer some concern for future reserves of carbon, as any processes that lead to a reduction of organic carbon in agricultural soils may be critical in terms of soil fertility, global food security and climate change (Wiesmeier et al., 2015). Copper concentrations were also significantly elevated in biochar-treated pore waters compared to controls (Fig S3; Table S1), probably due to mobilisation by DOC. Dissolved organic carbon is the most mobile fraction of organic ligands that exist in soils and may assist in the transfer of metals through soil as organic complexes (Cao et al., 2003); greater concentrations of aromatic and phenolic compounds will produce soluble metal-organic complexes (Tapia et al., 2010; Vaca-Paulín et al., 2006). Copper mobility has been shown to increase with increasing DOC concentration and $\mathrm{pH}$ (Temminghof et al., 1997; Strobel et al., 2001), whilst Zhou and Wong (2001) reported that application of soluble organic carbon from sewage sludge reduced $\mathrm{Cu}$ sorption in soil due to development of soluble complexes, with the effect being greater at higher $\mathrm{pH}$. There were no significant differences in pore water $\mathrm{Zn}$ and $\mathrm{Mn}$ concentrations compared to controls (Figs S4 and S5). In a study by Wong et al., (2007), soluble organic carbon did not affect $\mathrm{Zn}$ mobility due to the lower affinity of $\mathrm{Zn}$ for organic compounds and the great influence of $\mathrm{pH}$ on $\mathrm{Zn}$ sorption. Overall $\mathrm{DOC}$ and $\mathrm{Cu}$ were most significantly affected by biochar applications followed by Fe (Table S1). 
The restricted pool of soil available for plant roots in a pot trial means that the results presented here require validation under field conditions before they can be considered as definitive. Nevertheless, as suggested by Domene et al., (2015), the importance of preliminary ecotoxicity testing of biochars before field application is an essential prerequisite.

\subsection{Soil $\mathrm{CO}_{2}$ efflux, aggregate formation and stability}

Significant differences were observed in $\mathrm{CO}_{2}$ efflux between biochar-treated and control soils $(\mathrm{p}=0.002)$ (Fig. 5.), indicating that biochar additions had stimulated microbial activity. Application of biochar can initially increase $\mathrm{CO}_{2}$ efflux due to mineralization of labile-C being decomposed by microbes (Smith et al., 2010) and the 'priming effect' as a result of enhanced decomposition of soil organic matter (Jones et al., 2011); the observed increase in pore water DOC in this study (Fig. 4) may explain the increase in microbial activity in the biochar-treated soils. Organic carbon is also one of the major binding agents of aggregates in soil particles and improves soil aggregate stability (An et al., 2010). Aggregates are groups of primary soil particles that bind together more strongly than surrounding particles (Soil Science Society of America 1997) and improve soils structural stability.

Organic materials are directly responsible for the formation of macroaggregates through the actions of fungal hyphae and microbial extracellular polysaccharide gums (Six et al., 2004). Biochar amendments may be beneficial in soils that have poor physical characteristics such as sandy soils (Abujabhah et al., 2016) but their effects will depend on the type of biochar, as chemical composition differs with different feedstocks (Unger et al., 2011).

Total organic carbon (TOC) was greatest in the $<0.063 \mathrm{~mm}$ fraction within all soils irrespective of treatment, but addition of biochars significantly improved TOC within this fraction compared to controls (Fig. 6.). Organo-mineral particles, formed as a result of reactions between refractory carbon on biochar and the surrounding soil may have augmented 
TOC residence time and pool size in microaggregates (Wu et al., 2009). Through a combination of physical protection and chemical complexation this carbon source may have been protected from microbial decay (Powers and Schlesinger, 2002).

In our study, addition of OS biochar improved aggregate formation $\left(\mathrm{MWD}_{\mathrm{D}}\right)$ and stability $\left(\mathrm{MWD}_{\mathrm{w}}\right)$ in both planted and unplanted soils, with macroaggregates dominating the OS planted treatments (Table 5). The presence of plant roots has been shown to enmesh fine particulates into more stable macroaggregates whilst providing decomposable organic residues, polysaccharide gums and polyvalent cations which all assist in the development of aggregate formation (Amézketa, 1999). Following dry sieving $\left(\mathrm{MWD}_{\mathrm{D}}\right)$, aggregate formation was observed to increase in the 4-2 and 2-1 mm fractions with OS biochar, whilst aggregate stability also improved with the same treatment (Table 5). Glaser et al., (2002) reasoned that improved aggregate stability through biochar amendment was due to oxidized carboxylic acid groups, on biochar particles, interacting with soil minerals. However, neither RD nor SW biochars had any effect on aggregate formation or improvement in stability compared to control soil in unplanted or planted treatments (Table 5); it may be that subtle differences in organic functional groups on biochar surfaces (Fig. 1.) may be responsible for changes in aggregate stability within this soil type. Ouyang et al., (2013) discovered that soil macroaggregate formation increased in the early stages of a 90-d biochar incubation study, peaked in the middle and then at the later stage decreased, with little effect on microaggregation; they proposed that biochar served as a habitat for microbial growth enhancing macroaggregation, which is similar to the effect of OS biochar in this study. As a consequence of the high $\mathrm{C}: \mathrm{N}$ ratio of biochar, this probably created conditions favourable to fungi (Bossuyt et al., 2001) which they suggested played a more important role in aggregate formation than bacteria (De Gryze et al., 2005). 
Complexation processes resulting from organic functional groups and/or microbial activity are the most likely mechanisms resulting in variation of aggregate stability over time. We hypothesise that labile organic carbon and the surface chemistry of OS biochar (Fig. 1) appear to work in combination to improve aggregation processes. Nevertheless, the surface chemistry and physicochemical properties of biochar are understood to change with time in soil environments (Lawrinenko et al., 2016). Cheng et al., (2008) for example, using FT-IR, showed increases in hydroxyl and carbonyl groups from biochars incubated for 12 months relative to freshly prepared biochars; due to ageing they reported increased carboxylation of biochar surfaces. Despite that, it is still unknown whether complexation by organic carbon functional groups, are from labile or refractory parts of the biochar (Mukherjee and Lal, 2013). Biochar application to agricultural soils may be affected by tillage processes, being brought to the surface and reacting with $\mathrm{O}_{2}$ which may enhance its oxidation (Lawrinenko et al., 2016). Clearly, further work in this area may lead to advancement of knowledge in terms of biochars ability to enhance soil aggregation and the effect ageing has on its surface chemistry.

\section{Conclusions}

The purpose of this investigation was to help improve the knowledge gap that exists with biochar incorporation to temperate sandy soils. There was no positive effect on wheat grain yield following addition of any of the biochars. Furthermore, micronutrients, particularly $\mathrm{Cu}$ and $\mathrm{Fe}$, were significantly reduced in wheat grain. Labile organic carbon released from the chars most likely stimulated microbial activity, however only OS biochar in association with plant growth, enhanced aggregate stability. Total organic carbon was significantly greater in microaggregate fractions in all biochar-treated soils, probably as a result of reactions between refractory carbon on biochar surfaces and the surrounding soil which may have augmented 
TOC residence time and pool size in this fraction. The combination of plant root exudates and surface chemistry of OS biochar appeared to work in combination to improve aggregation processes. Over size material, derived from municipal and domestic green waste collections, has a highly varied provenance which resulted in differences in carbon functional groups on the pyrolysed biomass surfaces, and may have aided aggregate formation within this soil type. In conclusion, care is proposed when applying such amendments to temperate sandy agricultural soils. Biochar feedstock must be considered judiciously as must the amended field's end use. Future studies are also required to elucidate the ageing effect on biochar and its effect on soil properties in the long term.

\section{Acknowledgements}

The authors wish to thank Louise Hartley, Hazel Clarke and Dave Williams, for their much needed assistance and technical support especially with the use of laser granulometery and carbon analysis. Also Jan Haycocks for her help with maintaining the glasshouse study and Thomas Leigh for his assistance in the production of the SEM images. 


\section{References}

Abadía, J., Abadía, A., 1993. Iron and plant pigments. In: Barton, L.L., Hemming, B.C. (Eds.), Iron Chelation in Plants and Soil Microorganisms. Academic Press, New York, pp. 327-343.

Abujabhah, I.S., Bound, S.A., Doyle, R., Bowman, J.P., 2016. Effects of biochar and compost amendments on soil physico-chemical properties and the total community within a temperate agricultural soil. App. Soil Ecol. 98, $243-253$.

Álvarez-Fernández, A., Abadía, J., Abadía, A., 2006. Iron deficiency, fruit yield and fruit quality. In: Barton, L.L., Abadía, J. (Eds.), Iron Nutrition in Plants and RhizosphericMicroorganisms. Springer, Dordrecht, Netherlands, pp. 85-101.

An, S., Mentler, A., Mayer, H., Blum, W.E.H., 2010. Soil aggregation, aggregate stability, organic carbon and nitrogen in different soil aggregate fractions under forest and shrub vegetation on the Loess Plateau, China. Catena 81, 226233.

Atkinson, C.J., Fitzgerald, J.D., Hipps, N.A., 2010. Potential mechanisms for achieving agricultural benefits from biochar application to temperate soils: a review. Plant Soil 337, 1-18.

Bossuyt, H., Denef, K., Six, J., Frey, S.D., Merckx, R., Paustian, K., 2001. Influence of microbial populations and residue quality on aggregate stability. Appl. Soil Ecol. 16, 195-208.

Bowen, H.J.M., 1974. Problems in the elementary analysis of standard biological materials. J. Radioanal. Chem. 19, $215-226$.

Brick, S., 2010. Biochar: Assessing the promise and risks to guide U.S. policy. Natural Resources Defence Council Issue paper p.18.

Cakmak, I., Tolay, I., Ozdemir, H., Ozturk, L., Kling, C.I., 1999. Differences in Zn efficiency among and within diploid, tetraploid and hexaploid wheats. Ann. Bot. 84, 163-171.

Cao, X.D., Ma, L.Q., Shiralipour, A., 2003. Effects of compost and phosphate amendments on arsenic mobility in soils and arsenic uptake by hyperaccumulator, Pteris vittata L. Environ. Pollut. 126, 157-167.

Cheng, C.H., Lehmann, J., Engelhard, M.H., 2008. Natural oxidation of black carbon in soils: changes in molecular form and surface charge along a climosequence. Geochim. Cosmochim. Acta 72, 15981610 .

Clemente, R., Dickinson, N.M., Lepp, N.W., 2008. Mobility of metals and metalloids in a multi-element contaminated soil 20 years after cessation of the pollution source activity. Environ. Pollut. 155, 254-261. 
Chan, K.Y., Xu, Z., 2009. Biochar: nutrient properties and their enhancement. In: Lehman, J., Joseph, S. (Eds), Biochar for Environmental Management. Earth-scan, London, pp. 66-84.

De Gryze, S., Six, J., Brits, C., Merckx, R., 2005. A quantification of short-term macroaggregate dynamics: influences of wheat residue input and texture. Soil Bio. Biochem. 37, 55-66.

De la Rosa, J.M., Paneque, M., Miller, A. Z., Knicker, H., 2014. Relating physical and chemical properties of four different biochars and their application rate to biomass production of Lolium perenne on a Calcic Cambisol during a pot experiment of 79 days. Sci. Total Environ. 499, 175-184.

Domene, X., Enders, A., Hanley, K., Lehmann, J., 2015. Ecotoxicological characterization of biochars: role of feedstock and pyrolysis temperature. Sci. Total Environ. 512-513,552-561.

Gartler, J., Robinson, B., Burton, K., Clucas, L., 2013. Carbonaceous soil amendments to biofortify crop plants with zinc. Sci. Total Environ. 465, 308-313.

Genc, Y., Humphries, J.M., Lyons, G.H., Graham, R.D., 2005. Exploiting genotypic variation in plant nutrient accumulation to alleviate micronutrient deficiency in populations. J. Trace Elem. Med. Biol. 18, 319-324.

Glaser, B., Lehman, J., Zech, W., 2002. Ameliorating physical and chemical properties of highly weathered soils in the tropics with charcoal - a review. Biol. Fert. Soils 35, 219-230.

Hartley, W., Uffindell, L., Plumb, A., Rawlinson, H. A., Putwain, P., Dickinson, N.M., 2008. Assessing biological indicators for remediated anthropogenic urban soils. Sci. Total Env. 405, 358-369.

Hotz, C., Brown, K.H., 2004. International Zinc Nutrition Consultative Group (IZiNCG) technical document \#1. Assessment of the risk of zinc deficiency in populations and options for its control. Food Nutr. Bull. 25, S94S203.

Iqbal, H., Garcia-Perez, M., Flury, M., 2015. Effect of biochar on leaching of organic carbon, nitrogen, and phosphorus from compost in bioretention systems. Sci. Total Environ. 521-522, 37-45.

Jay, C.N., Fitzgerald, J.D., Hipps, N.A., Atkinson, N.A., 2015. Why short-term biochar application has no yield benefits: evidence from three field-grown crops. Soil Use Manage. 31, 241-250.

Jones, D.L., Murphy, D.V., Khalid, M., Ahmad, W., Edwards-Jones, G., DeLuca, TH., 2011. Short-term biochar-induced increase in soil $\mathrm{CO}_{2}$ release is both biotically and abiotically mediated. Soil Biol. Biochem. 43, 1723-31. 
Kappler, A., Wuestner, M.L., Ruecker, A., Harter, J., Halama, M., Behrens, S., 2014. Biochar as electron shuttle between bacteria and Fe (III) minerals. Environ. Sci. Technol. Lett. 1 (8), 339-344.

Katz, S.A., 2002. Bowens kale: a brief review dedicated to the late Professor Humphrey John Moule Bowen (19292001). J. Radioanal. Nucl. Chem. 251, 3-5.

Kemper, W.D., Rosenau, R.C., 1986. Aggregate stability and size distribution. In: Klute, A., (Ed), Methods of soil analysis. Part 1. Physical and mineralogical methods. ASA and SSSA, Madison, WI, USA. pp. 425-444.

Lin, Y., Munroe, P., Joseph, S., Kimber, S., Van Zwieten, L., 2012. Nanoscale organo- mineral reactions of biochars in ferrosol: an investigation using microscopy. Plant Soil 357, 369-380.

Lawrinenko, M., Laird, D. A., Johnson, R. L., Jing, D., 2016. Accelerated aging of biochars: Impact on anion exchange capacity. Carbon, 103, 217-227.

Le Bissonnais, Y., 1996. Aggregate stability and assessment of soil crustability and erodibility.1. Theory and methodology. Eur. J. Soil Sci. pp. 425-437.

Lehmann, J., da Silva Jr., J.P., Steiner, C., Nehls, T., Zech, W., Glaser, B., 2003. Nutrient availability and leaching in an archaeological Anthrosol and a Ferralsol of the Central Amazon basin: fertilizer, manure and charcoal amendments. Plant Soil 249, 343-357.

Lehmann, J., 2007. Bio-energy in the black. Front. Ecol. Environ. 5, 381-387.

Lehmann, J., Joseph, S., 2009. Biochar for environmental management: an introduction. In: Lehmann, J., Joseph, S., (Eds). Biochar for environmental management - science and technology. Sterling, VA: Earthscan. pp. 1-12.

Liang, B., Lehmann, J., Solomon, D., Sohi, S., Thies, J.E., Skjemstad, J.O., Luizao, F.J., Engelhard, M.H., Neves, E.G., Wirick, S., 2008. Stability of biomass derived black carbon in soils. Geochimica et Cosmochimica Acta. 72, 6096-6078.

Liang, C., Gascó, G., Fu, S., Méndez, A., Paz-Ferreiro, J., 2015. Biochar from pruning residues as a soil amendment: Effects of pyrolysis temperature and particle size. Soil and Tillage Research. http://dx.doi.org/10.1016/j.still.2015.10.002

Liu, J., Schulz, H., Brandl, S., Miethke, H., Huwe, B., Glaser, B., 2012. Short-term effect of biochar and compost on soil fertility and water status of a Dystric Cambisol in NE Germany under field conditions. J. Plant Nut. Soil Sci. $175,698-707$. 
McLaughlin, M.J., Williams, C.M.J., McKay, A., Kirkham, R., Gunton, J., Jackson, K.J., et al. 1994. Effect of cultivar on uptake of cadmium by potato-tubers. Aust. J. Agric. Res. 45, 1483-95.

Molnár, M., Vaszita, E., Farkas, É., Ujaczki, É., Fekete-Kertész, I., Tolner, M., Klebercz, O., Kirchkeszner, C., Gruiz, K., Uzinger, N., Feigl, V., 2016. Acidic sandy soil improvement with biochar - A microcosm study. Sci. Total Environ. http:// dx.doi.org/10.1016/j.scitotenv.2016.01.091

Moreno-Jiménez, E., Fernández, J.M., Puschenreiter, M., Williams, P.N., Plaza, C., 2016 Availability and transfer to grain of $\mathrm{As}, \mathrm{Cd}, \mathrm{Cu}, \mathrm{Ni}, \mathrm{Pb}$ and $\mathrm{Zn}$ in a barley agri-system: Impact of biochar, organic and mineral fertilizers. Agric. Ecosys. Env. 219, 171-178.

Mukherjee, A., Lal, R., 2013. Biochar impacts on soil physical properties and greenhouse gas emissions. Agronomy 3 , 313-339.

Novak, J.M., Busscher, W.J., 2012. Selection and use of designer biochars to improve characteristics of southeastern USA Coastal Plain degraded soils. In: Lee, J.W., (Ed). Advanced Biofuels and Bioproducts. Springer Science media. USA. pp. 69-96.

Ortiz-Monasterio, J.I., Palacios-Rojas, N., Meng, E., Pixley, K., Trethowan, R., Pena, R.J., 2007. Enhancing the mineral and vitamin content of wheat and maize through plant breeding. J. Cereal Sci. 46, 293-307.

O’Neill, B., Grossman, J., Tsai, M.T., Gomes, J.E., Lehmann, J., Peterson, J., Neves, E., Thies, J.E., 2009. Bacterial community composition in Brazilian Anthrosols and adjacent soils characterized using culturing and molecular identification. Microbial Ecology 58, 23-35.

Ouyang, L., Wang, F., Tang, J., Yu, L., Zhang, R., 2013. Effects of biochar amendment on soil aggregates and hydraulic properties. J. Soil Sci. Plant Nutr. 13, 991-1002.

Powers, J.S., Schlesinger, W.H., 2002. Relationships among soil carbon distributions and biophysical factors at nested spatial scales in rain forests of northeastern Costa Rica. Geoderma 109, 165-190.

Saygin, S. D., Cornelis, W. M., Gunay, E., Gabriels, D., 2012. Comparison of different aggregate stability approaches for loamy sand soils. App. Soil Ecol. 54, 1-6.

Soil Science Society of America. Glossary of soil science terms. 1997. SSSA, Madison, WI.

Sorrenti, G., Masiello, C. A., Toselli, M. 2016. Biochar interferes with kiwifruit Fe-nutrition in calcareous soil. Geoderma. 272, 10-19. 
Six, J., Bossuyt, H., Degryze, S., Denef, K., 2004. A history of research on the link between (micro) aggregates, soil biota, and soil organic matter dynamics. Soil Till. Res. 79, 7-31.

Smith, J.L., Collins, H.P., Bailey, V.L., 2010. The effect of young biochar on soil respiration. Soil Biol. Biochem. 42, $2345-47$.

Strobel, B.W., Hansen, H.C.B., Borggaard, O.K., Andersen, M.K., Raulund-Rasmussen, K., 2001. Cadmium and copper release kinetics in relation to afforestation of cultivated soil. Geochimica et Cosmochimica Acta. 65, 1233-1242.

Sun, F., Lu, S., 2014. Biochars improve aggregate stability, water retention, and pore-space properties of clayey soil. J. Plant Nut. Soil Sci. 177, 26-33.

Tapia, Y., Cala, V., Eymar, E., Frutos, I., Gárate, A., Masaguer, A., 2010. Chemical characterization and evaluation of composts as organic amendments for immobilizing cadmium. Bioresour. Technol. 101, 5437-5443.

Temminghof, E.J.M., van der Zee, S.E.A.T.M., de Haan, F.A.M., 1997. Copper mobility in a copper contaminated sandy soil as affected by pH, and solid and dissolved organic matter. Environ. Sci. and Tech. 31, 1109-1115.

Thompson, B.., 2011. Combating Fe deficiency: food-based approaches. In: Thompson, B., Amoroso., L (Ed). Combating micronutrient deficiencies: food-based approaches. CABI, Wallingford, UK. pp. 268-288.

Unger, R., Killorn, R., Brewer, C., 2011. Effects of soil application of different biochars on selected soil chemical properties. Commun. Soil Sci. Plant Anal. 42, 2310-2321.

Vaca-Paulín, R., Esteller-Alberich, M.V., Lugo-de la Fuente, J., Zavaleta-Mancera, H.A., 2006. Effects of sewage sludge or compost on the sorption and distribution of copper and cadmium in soil. Waste Manage. 26, 71-81.

Van Zwieten, L., Kimber, S., Morris, S., Chan, K.Y., Downie, A., Rust, J., Joseph, S., Cowie, A., 2010. Effects of biochar from slow pyrolysis of papermill waste on agronomic performance and soil fertility. Plant Soil 327, $235-246$.

Wiedner, K., Naisse, C., Rumpel, C., Pozzi, A., Wieczorek, P., Glaser, B., 2013. Chemical modification of biomass residues during hydrothermal carbonization-what makes the difference, temperature or feedstock? Org. Geochem. 54, 91-100.

Wiesmeier, M., Hübner, R., Kögel-Knabner, I., 2015. Stagnating crop yields: An overlooked risk for the carbon balance of agricultural soils? Sci. Total Environ. 536, 1045-1051.

Wong, J.W.C., Li, K.L., Zhou, L.X., Selvam, A., 2007. The sorption of Cd and Zn by different soils in the presence of dissolved organic matter from sludge. Geoderma 137, 310-317. 
Woolf, D., Amonette, J.E., Street-Perrott, F.A., Lehmann, J., Joseph, S., 2010. Sustainable biochar to mitigate global climate change. Nature Communications 1. Article number: 56 (online journal) www.nature. com/ncomms/journal/v1/n5/full/ncomms1053.html.

Wu, Q-B., Wang, X-K., Ouyang, Z-Y., 2009. Soil organic carbon and its fractions across vegetation types: effects of soil mineral surface area and microaggregates. Pedosphere 19, 258-264.

Zhang, J., Liu, J., Liu, R.L., 2015. Effects of pyrolysis temperature and heating time on biochar obtained from the pyrolysis of straw and lignosulfonate. Bioresour. Technol. 176, 288-291.

Zhou, L.X., Wong, J.W.C., 2001. Effect of dissolved organic matter from sludge and sludge compost on soil copper sorption. J. Environ. Qual. 30, 878-883. 